\title{
CHICAGO COURT OF DOMESTIC RELATIONS
}

\author{
By William N. Gemmill,
}

Judge of the Municipal Court of Chicago; President of the Illinois Branch of the American Institute of Criminal Law and Criminology.

This unique court was organized in April, 1911, by a resolution adopted by the judges of the municipal court. Under an act of the legislature creating this court, the judges were given the power to establish branch courts, and to prescribe the procedure for them. All cases involving wife and child desertion, contributing to the dependency or delinquency of children by parents and others, violations of the child labor law, and the law forbidding women to work more than ten hours during any one day, actions for selling liquor and cigarettes to minors, violations of the truancy laws, and actions in bastardy and against abortion are now all brought together in one centralized court and tried by one judge sitting continuously in that court. This court is called the court of domestic relations.

For the first year of the court, Chief Justice Harry Olson assigned Associate Judge Charles N. Goodnow to preside, and the writer was assigned in the same manner, for the second year, ending April 30, 1913.

While presiding over this court during the last year, the writer tried 3,699 cases, in 2,024 of which either the wife alone or the wife and children were deserted by the husband and father. To one who has listened through the whole year to the harrowing stories of abuse, privation, amounting often to starvation, as told by these deserted women and children, it becomes very apparent that women not only have a greater capacity than men for undergoing suffering and enduring hardship, but that they exhibit a greater loyalty towards their children and their dependent blood relations. Notwithstanding the fact that hundreds of these deserted women are often left, sometimes in the midst of severe winter, with several children dependent upon them, they always keep up the struggle, often by taking in washing, doing scrubbing, or other similar work, and at a great personal sacrifice, to keep the family together, and save them from starvation. 
The court of domestic relations, so far as I know, is the only one ever created whose primary function is to keep the family together. Our divorce courts were organized to separate families. Seldom is an effort made in them to reunite those who, for some reason, have found their married relations uncongenial. But during the last year more than 50 per cent of the divided families brought into the court of domestic relations were induced, through the intercessions of the court, to reunite and forget the mistakes of the past, so far as possible, in the interest of the larger purpose of keeping the families together, by making the home a fit place for the growth of children. It is, however, not always desirable that separated families should be reunited. It often happens that the cause for the separation is one of a nature which makes it imperative that the husband and wife should not again live together. Our education has led to the view that marriage is always to be encouraged and divorce discouraged. If, however, our race is to be more virile than it is today, we must change this view. No day passes in the court of domestic relations but that the judge is called upon to listen to some terrible life tragedy. A young girl full of hope, ambitious, with high ideals, met and married a man whom she had every reason to believe was pure, and possessed of ideals as lofty as her own. Scarcely, however, had the marriage taken place, when she discovered that instead of to a man, she had bound herself for life to a monster, and life offered nothing to her, and the children that might be born to her, but unspeakable torment. For such as these, marriage is a curse, and divorce a great blessing. We hear it said that divorce destroys the sanctity of the home. Few people, however, imagine how many homes there are where the only thing left for divorce to destroy is inhuman and unspeakable cruelty, and the possibility of multiplying the increasing army of defectives and criminals. We have many moral reformers who say that a young woman having once made the fatal mistake of being led to the altar by a man of this sort, should be compelled to continue her life with him, although by so doing she will never know a single hour not filled with unutterable sorrow and bitterest disappointment. In this day of progress we are becoming more humane. There is not a criminal, no matter how grave his offense, but may hope for pardon and parole, and thus another opportunity to begin life anew. Why should we shut the doors of hope to the thousands of women whose only offense was to love madly, but not wisely? 
During the last year I tried, by means of a card index, to arrive at some of the causes which separate families. Whenever an applicant came into court he or she was first met by a young lady, assistant to the judge, who made careful inquiry into the family history of the applicant. All such data were recorded upon a large card kept for that purpose. If the case was an ordinary one involving wife abandonment, or some other well-known offense, coming within the jurisdiction of this court, this assistant prepared the formal complaint and warrant for the arrest of the delinquent party, all of which she thereafter presented to the judge, either in chambers or upon the bench. If the case was an unusual one the applicant was brought directly before the judge before any further steps were taken. Upon the same card, blank spaces were left for the judge to record his conclusions, after hearing the case upon the trial. If a woman was deserted upon one day it often followed that she would apply to the court on the same day, and a warrant was issued for her recreant husband. It frequently occurred that before the husband had been able to board a train with his paramour upon the day of his desertion, he was seized and brought before the court.

Of the 3,699 cases tried during the year, over 2,000 of them were heard within one week after the complaint was made to the court, and in the 2,024 cases in which husbands were charged with deserting their wives and children, the husbands were arrested and brought before the court, and an order entered for the payment of money, for the support of their dependent families, in more than three-fourths of the cases, within two days after the first complaint was made to the court. The following is a summary of my conclusions as registered upon this card, and filed for record in the case. In each instance the data were registered either during the hearing of the cause or immediately afterwards. This table has to do altogether with cases of wife and child abandonment. Like tables were kept in all other classes of cases. The causes for such abandonment were as follows:

Per cent

Excessive use of intoxicating liquors.................... 46

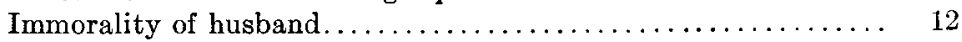

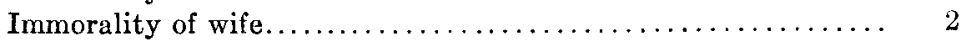

Ill-temper and abuse by husband $\ldots \ldots \ldots \ldots \ldots \ldots \ldots \ldots \ldots, 8$

Ill-temper and abuse by wife $\ldots \ldots \ldots \ldots \ldots \ldots \ldots \ldots \ldots \ldots, \ldots \ldots \ldots$

Venereal disease of husband $\ldots \ldots \ldots \ldots \ldots \ldots \ldots \ldots \ldots \ldots, 12$ 


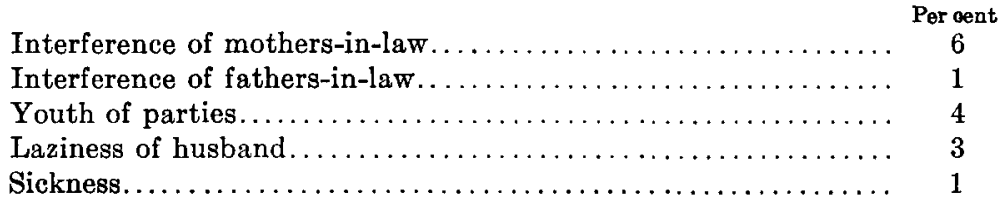

While our records show that, in a great majority of instances, the greatest blame rests upon the husband and father for breaking up the home, yet in very many instances the women are the greater offenders. Nor is this to be wondered at. In a large city most of the women are confined during the greater part of their lives within the narrow walls of a flat or tenement house. They are often surrounded by warring and disagreeable neighbors who make life a burden to themselves and to all those coming near them. The result is that they become irritable and disagreeable, and their husbands at night become the objects of their stored-up wrath.

By reason of the great power conferred upon this court it is able to compel many drunken, lazy and shiftless men to contribute quite largely to the support of their families. The court has the power to take summary action in all cases involving family support. A deserting husband finds, when he is brought before the court, that he has only one alternative; he must support his family or go to the Bridewell. If he shows an unwillingness to support the family he finds himself upon the way to the Bridewell within an hour after such unwillingness is displayed to the court. The result of this action, in a financial way, during the last year was that $\$ 75,562.59$ was paid into the court by men of this kind, and by the court paid out, for the support of dependent families. An additional sum of almost an equal amount was likewise paid upon order of the court directly by the men to their families, without passing through the court.

We are, however, greatly handicapped, by reason of the failure of the Illinois statutes to provide that workhouses, wherein prisoners are employed, be required to pay a portion of the earnings of such prisoners to their dependent families. In Illinois nothing is paid by the state or the city to such families, although the heads of the families are required to work constantly during the terms of their imprisonment. This thrusts upon philanthropic organizations and private charities the burden of caring for these families, a burden which is becoming altogether too heavy for them to carry. It is the aim of the court in dealing with cases of wife abandonment to permit the 
offending husband to go upon parole, whenever he gives a bond with proper surety conditioned upon the payment of a certain fixed sum for the support of his family. The greatest difficulty arises, however, by reason of the fact that many wife deserters have no financial means, and are unable to secure anyone to execute a bond in their behalf. The court is, therefore, faced in all such cases, with the alternatives of either allowing such persons to sign their own bonds, trusting to their honor to make payments as prescribed in the bond, or of sending them to the Bridewell. In nearly all cases the first alternative is adopted and such persons, unless they are of known bad character, are permitted on parole upon signing their own bonds. It frequently happens, however, that being released they fall into their old habits, and fail to make the payments, as ordered by the court. It often follows that such persons are arrested sometimes three or four different times and brought before the court in an effort, only partly successful, to secure the needed family support. In most of such cases the threat of the workhouse arouses a wholesome fear, that brings to the court many thousands of dollars, for the support of needy families. There are, however, many men who have fallen so low that even the Bridewell has no terrors for them. Indeed, in not a few instances when deserting husbands were told by the court that they must either support their families or go to the Bridewell they gleefully accepted the latter alternative.

Prior to a few months ago the wife abandonment statute of Illinois had been construed by our courts as making wife abandoment a continuing offense. A recent decision of the supreme court of this state declared otherwise, so that under the act as it stands today, a husband once convicted of abandoning his wife can only be held for her support for a period of one year, and unless he rejoins her after that time, he can never again be charged with her abandonment. This unfortunate interpretation of the statute greatly hampers the work of the court and the accomplishment of justice.

During the last year 499 couples were brought before the court in bastardy actions. The writer married 162 of these couples. Judgments aggregating $\$ 165,000$ were entered in these cases. Under the Illinois statute the defendant when found guilty may be ordered to pay the sum of $\$ 550$ to the prosecutrix for the support of the child, this to be paid through a period of nine years. Fifty-one per cent of the women involved in these cases were domestics. It has been 
said that in many cases of this kind the women were led to their downfall by reason of low wages, etc. A careful analysis, however, of the cases before the court last year does not demonstrate the truthfulness of the assertion.

In 130 cases before the court last year men were charged with contributing to the delinquency of girls. The offense generally consisted in taking girls to hotels or disorderly houses. A few of these men were hardened characters, who cared nothing for the effect their conduct would have upon the lives of such girls, but by far the larger number of men so brought before the court were but boys ranging in age from fifteen to twenty years. Most of these boys had been led to commit their first crime through a chance meeting, upon the street, with one or more of these young girls, most of whom are from fourteen to seventeen years of age. Few people realize how many such girls there are upon the public streets of most any town or city, and fewer people realize the individual power for evil of such girls when they have gotten out from under parental restraint and are permitted unhindered to run upon the public streets at all hours of the night.

During the last year in the court of domestic relations the writer tried 210 persons charged with violating the child labor law and the laws prohibiting the selling of liquor, tobacco and cigarettes to minors, and 98 cases involving the violations of the law forbidding the employment of women for a period of more than ten hours during any one day. The child labor law of Illinois has had a most beneficial effect in taking children out of factories, workshops and department stores, and in limiting the hours of their employment. There is, however, a danger not well understood by the average citizen, growing out of the strict enforcement of this law. In Illinois no child under the age of fourteen years can ever legally be employed at any gainful occupation, and children between the ages of fourteen and sixteen years cannot be employed during the months when school is in session, unless a certificate is obtained from the school authorities, permitting such employment. One of the results of the rather strict enforcement of this law has been to turn hundreds and thousands of bright young boys upon the streets, especially during the summer months when school is not in session. They meet in groups in alleys, play marbles, craps and engage in other games of doubtful character. Here the good boy meets the vicious boy and together they plan some escapade which usually results disastrously to both. 
It is altogether right and proper that children under the age of fourteen years should not be employed at certain tasks, such as work in factories, etc., but boys of this age should be permitted to perform certain kinds of light work, especially during the school vacations, and to run errands after school under certain circumstances, and thus cultivate habits of industry, and arouse laudable ambitions.

Many saloon-keepers and dealers in cigarettes and tobacco have been arrested and fined for selling to children. It is my opinion that not enough emphasis is given to the need of a strict enforcement of the law against the sale of liquor and cigarettes to minors. I have tried more than 25,000 criminal and quasi-criminal cases, and while it would be altogether untrue to say that all cigarette users are criminals, yet it is true that almost every criminal, degenerate, defective and delinquent man or woman brought before the court, was a user of cigarettes, and nearly every truant was found to be addicted to the habit. In the vast majority of these cases the most unfailing accompaniments of the degenerate, professional criminal, defective and feeble-minded individual are the yellow-stained fingers, the discolored lips, the dimmed and water-soaked eyes, dullness of hearing, and the absence of almost all moral perception.

The court of domestic relations is now a firmly established institution. Its moral force in the community is most salutary. Thousands of men upon whom the responsibilities of married life rest lightly are kept in a fairly straight and narrow path by a knowledge of the fact that there is an institution well equipped to mete out summary punishment to wife and child deserters. No one unfamiliar with the court can appreciate the range of its activities. Family skeletons are always on parade; usually from twenty to fifty stalk in and out of the court every day; some of them are most hideous; others are mirth-provoking and welcome, for they relieve the tension. But few lawyers appear in the court. In not over one out of five cases does a lawyer appear on either side. Nearly all of the questions are put by the judge and are aimed to reach the heart of the trouble by the most direct route. The one all-embracing question is at once addressed to the deserting husband, who is now thoroughly sobered by his arrest. That question is, "Why did you leave home?" If all the answers to it during one month could be compiled, they would make interesting reading. The volume could be used to point many moral lessons, but it could also be used as a valuable 
joke book. Here are a few of the answers: Daley left home, as he said, because his wife refused to wear mourning to her mother-inlaw's funeral. When I turned to the wife and asked why she did not wear the accustomed black, she promptly replied: "I am no hypocrite; I was not sorry the old thing died and I was not going to make anybody think I was." Another said he left home because his wife persisted in wearing her kimono to the breakfast table. When I asked her why such conduct, she replied that she was brought up that way and she never would change. Another said he left home because the bill for his mother-in-law's false teeth came with his monthly grocery bill. Another, a pretty young Swedish girl, married to an artist, said she left home because her mother-in-law went everywhere with them on their honeymoon.

In many cases the court was called upon to determine how much a wife, whose husband earns from $\$ 15$ to $\$ 20$ per week, should pay for her spring or fall hat. In many other cases the question for the court's solemn adjudication was how many afternoons during a week may a wife go to the movies and properly take care of her home. In others the all-important question was how much the wife should allow her husband during the week for carfare, beer and cigars. I found the usual allowance by a thrifty housewife was 5 cents per day. A frequent complaint by one side or the other was the infrequent intervals between baths, and the court had judicially to determine what was a proper interval.

A day seldom passed in this court when from one to five women were not carried from the room in an unconscious or semi-conscious condition due very often to epilepsy or to some other form of incurable disease.

Last year we established two extra rooms in connection with the court, one where the children might wait with their mothers until the cases in which they were interested were called for hearing. In this large room were kept tables upon which was furnished the latest reading matter, and many rocking chairs and blocks from which the children could erect houses, etc. In the other room several children's cots were placed and no day passed without some unfortunate babes sleeping upon these cots entirely unconscious of the work going on, for their care, in the court outside. It often happens that from five to ten or fifteen babies are brought to the court in a single day. Many of these babies are not over one week old. For 
the care of these children and their mothers the court has now employed a nurse, who devotes her whole time to this service. Milk is also supplied for the use of the waiting children.

While the court is doing much in an advisory way in helping to reëstablish broken homes, yet too much emphasis must not be placed upon this kind of work, for the presiding judge is called upon every day to enforce the law with rigor. It is the fear of the penalties which the law prescribes which enables the court to obtain any kind of justice for the injured. Take away from the court of domestic relations this power to punish without ceremony or delay the evil-doer, and the court would lose all its efficiency. No day passes but what it becomes necessary, in order to break down the stubborn will of a wife deserter, that he be sent to the workhouse. Usually within an hour or often within ten minutes from the time he is arraigned in court he finds himself upon the way to the Bridewell. After he has been there a day, possibly two or three days, a great change comes over him and he sends a most urgent appeal to the court to release him on parole. Accompanying such an appeal is a promise henceforth to provide properly for his family. It follows, therefore, that while the court daily sends many wife deserters to prison, it brings back from the prison in the course of a week a number substantially equal to the number sent, and a new opportunity is offered. One such committal is usually sufficient to accomplish the court's purpose. It is sometimes necessary, however, that the same person be committed two, three and four times before his lesson is thoroughly learned.

In advocating law reforms, in order to secure social justice, it is all-important to keep in mind the urgent need of keeping the law strong and virile, and in making the penalties for its violation real and substantial. 